$\mathbb{T}$ periodica polytechnica

\author{
Civil Engineering \\ 58/4 (2014) 371377 \\ doi: $10.3311 /$ PPci.7239 \\ http://periodicapolytechnica.org/ci \\ Creative Commons Attribution (1) \\ RESEARCH ARTICLE
}

\section{Soil Modification by the Application of Steel Slag}

Isaac Akinwumi

Received 2013-12-21, revised 2014-05-31, accepted 2014-10-08

\begin{abstract}
This paper provides experimental insights on the modification of a soil using electric arc furnace (EAF) steel slag, which is limitedly used as a construction material because of its volumetric instability. Various percentages of pulverized steel slag were applied to a soil, having poor engineering properties, with the aim of improving the engineering properties of the soil. Sieve analysis, consistency limits, specific gravity, compaction, California bearing ratio $(C B R)$, unconfined compression and permeability tests were performed on the soil and each of the soil-slag mixtures. The plasticity and the uncured strength of the soil were reduced and increased, respectively, by the addition of an optimal steel slag content of 8\%. Pulverized steel slag is therefore recommended as a low-cost modifier or stabilizer of lateritic soils with poor engineering properties, because it made the soil sample in this study better suited for use as a road pavement layer material.
\end{abstract}

\section{Keywords}

steel slag · lateritic soil · soil modification · geotechnical properties

Department of Civil Engineering, College of Engineering, Covenant University, Ota, P.M.B. 1023, Nigeria

e-mail: isaac.akinwumi@covenantuniversity.edu.ng

\section{Introduction}

It is becoming more attractive to reuse and recycle industrial wastes rather than disposing them off. Steel slag, a by-product of the conversion of iron to steel, is one of the industrial wastes having a large percentage still being disposed off in landfills and on dumpsites. Past years, steel slag was not attractive because of the availability of large amount of blast furnace slag, which is considered more stable for direct use as a construction material than steel slag.

In 2002, 50 million metric tons of steel slag was estimated to be produced worldwide [4] and 12 million tons was estimated to be produced in Europe [14]. Currently, the world annual production of steel slag is estimated to range between $90-135$ million metric tons.

Approximately 15 to $40 \%$ of the $10-15$ million metric tons of steel slag generated in the United States in 2006 was not utilized [24] and a larger percentage of the $0.35-0.45$ million metric tons of steel slag estimated by Akinwumi et al. [2] to be generated annually in Nigeria is disposed-off in an environment-unfriendly manner.

Steel slag is generally categorized based on its raw materials and production process into basic oxygen furnace (BOF) slag and electric arc furnace (EAF) slag. Unlike blast furnace slag, BOF and EAF slags contain high unhydrated lime $(\mathrm{CaO})$ that causes it to volumetrically expand [19,23] and this limits its use as a construction material.

Researchers found out that steel slag can be used for manufacturing blended cement [4, 13, 18, 22]; used as aggregate in Portland cement concrete and asphalt concrete [1, 12, 14]; and as unbound granular materials for road bases and sub-bases [14]. However there is no work on mixing EAF slag with soils (and especially lateritic soil) for improvement of its geotechnical properties in order to use the blend or mixture as a pavement layer material.

This research effort focuses on investigating how pulverized EAF slag modifies the plasticity, strength and permeability of a lateritic soil, and identifies the extent of the correlation between each of these engineering properties and the addition of steel slag. 
Lateritic soils occur mostly under climatic conditions of high rainfall and temperature, and result from chemical decomposition of rocks (igneous, sedimentary or metamorphic) with subsequent alteration of its silica and sesquioxide contents, such that the ratio of silica-sesquioxide falls within the range of 1.33 and 2.00 .

They are readily available in some countries in Africa, Australia, Central America, South America, South Asia and Southeast Asia [10] and their utilization as a construction material within these regions become economically attractive. Though readily available, some lateritic soils have high plasticity, poor workability, low strength, high permeability, tendency to retain moisture and high natural moisture content [10]. Thus, they do not meet existing standard or local requirements for use in engineering projects.

However, in order to keep overall construction project cost as low as possible without mortgaging quality, Highway Design Engineers have resorted to modifying or stabilizing these soils. Using steel slag, a waste, for this purpose will be more costeffective while also minimizing its eventual disposal.

\section{Materials and methods}

Soil sample used in this research work was collected, by method of bulk disturbed sampling (for homogeneity), from the borrow pit of Covenant University behind the university student hostels. It was collected at a depth not less than $0.5 \mathrm{~m}$ from the ground, after the removal of $0.2 \mathrm{~m}$ thick topsoil layer. A small amount was collected in a polythene bag to avoid moisture loss during transportation and before the determination of the natural moisture content of the soil in the laboratory. The samples were stored and air-dried in the Geotechnics laboratory of the Department of Civil Engineering, Covenant University, Ota.

The hydration of free calcium and magnesium oxides contained in steel slag is known to be responsible for its volumetric instability, which limit its utilization for geotechnical engineering application. Exposures of steel slag to weather for 6 12 months have been identified [9] to reduce these oxides and consequently its expansive nature. Consequently, black cobblesized steel slag samples, collected from a stockpile adjacent to Justrite Supermarket along Idiroko Road in Ota, that had been exposed to weather for eight months and air-dried in the laboratory for another four months were utilized during this research. These samples were pulverized such that $75 \%$ of the samples passed through $75 \mu \mathrm{m}$ sieve openings while all the samples passed through $0.425 \mathrm{~mm}$ sieve openings.

The oxide composition of the soil was determined using atomic absorption spectrophotometer while the chemical composition of the pulverized steel slag was obtained using standard X-ray fluorescence spectroscopy. A typical range of chemical composition of EAF slag presented by [5], after testing 48 EAF slag samples, is graphically presented in Fig. 1 as an envelope for comparison with the result of chemical composition of the steel slag sample. Natural moisture content, specific grav- ity, sieve analysis and Atterberg's limits, compaction, California bearing ratio (CBR), unconfined compression and permeability tests were performed on the natural soil sample and on the soilslag mixtures of 5, 8 and $10 \%$ steel slag, by weight of the dry soil sample. Each of these tests was performed in triplicate and the mean is what is presented. These tests were selected because most of the standards [15, 20, 21] available in tropical countries of Africa use these engineering properties to provide the benchmark for selection of materials to be used as subgrades, subbases and road bases. The effects of adding steel slag to modify these engineering properties of the soil sample were determined. The procedures for the various tests were carried out in accordance with BSI [6].

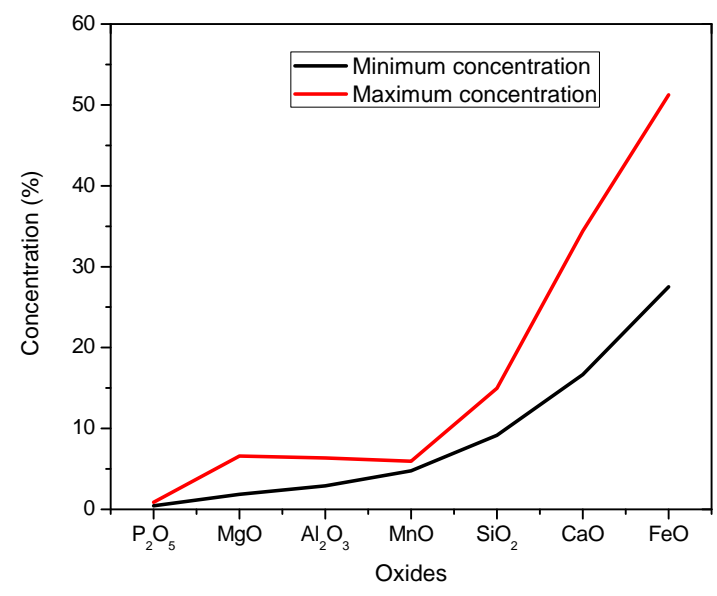

Fig. 1. Typical oxide composition envelope of EAF steel slag

\section{Results}

In order to determine the level or extent of laterization of the soil used, the percentage concentration of oxides of silica $\left(\mathrm{SiO}_{2}\right)$, iron $\left(\mathrm{Fe}_{2} \mathrm{O}_{3}\right)$ and aluminum $\left(\mathrm{Al}_{2} \mathrm{O}_{3}\right)$ in the soil were determined. A ternary or tri-plot of this composition is shown in Fig. 2, the soil contains higher silica content when compared with the iron oxide content. This suggests that this soil was formed from laterite on an acidic rock and it contains some quartz. The ratio of silica-sesquioxides was determined to be 1.45. Thus, confirming that the soil is lateritic. According to the Schellmann [17] scheme of classification of weathering products, this soil sample was taken from a weakly laterized profile.

The chemical composition of the EAF slag used, expressed in terms of oxides and calculated from elemental analysis determined by X-ray fluorescence, is presented in Fig. 3 .

The concentration of $\mathrm{CaO}, \mathrm{MgO}, \mathrm{SiO}_{2}$, and $\mathrm{MnO}$ fell out of the envelope for the typical chemical composition of steel slag. $\mathrm{CaO}, \mathrm{MgO}$ and $\mathrm{SiO}_{2}$ had their concentration falling below the minimum concentration, most likely due to the leaching away of these oxides after exposure of the steel slag to weather. The concentration of $\mathrm{MnO}$, however, is above the upper-bound of the envelope. There might have been excess addition of manganese, 


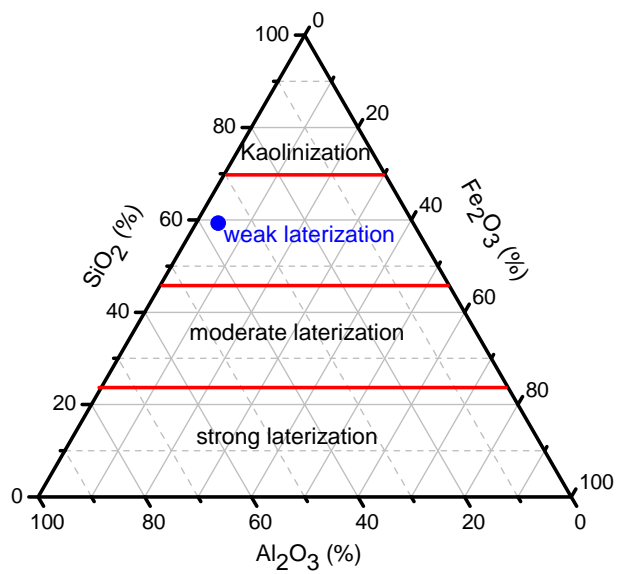

Fig. 2. Tri-plot of some oxides of the soil

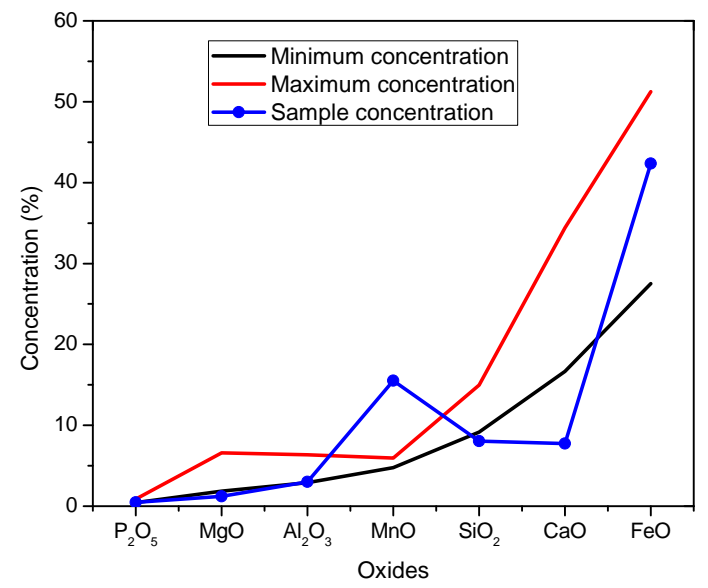

Fig. 3. Oxide composition of the steel slag

an alloying element that improves the mechanical properties of steel during its production.

A summary of the result of the geotechnical properties of the soil prior to addition of steel slag is presented in Tab.11 The soil, which is brown, contains about $50 \%$ of fines and a large percent of sand (Fig. 4), which is in agreement with the silica content or quartz in the soil. The soil is classified as A-7-6(5) according to the American Association of State Highway and Transportation Officials (AASHTO) soil classification system and has a natural moisture content of $14.3 \%$.

With its plasticity index greater than 11, the fines are clayey, according to AASHTO system and the engineering properties of such a soil are mostly influenced by its mineralogy.

The activity of the soil was calculated to be 0.5 and consequently classified as inactive. Using the activity, liquid limit, plastic limit and plasticity index of the soil, alongside the tables of the activity of clay-rich soils and typical Atterberg limits for soils provided by Budhu [7], this soil can be described as containing predominantly kaolinite. Kaolinite in any soil gives it a higher degree of stability.

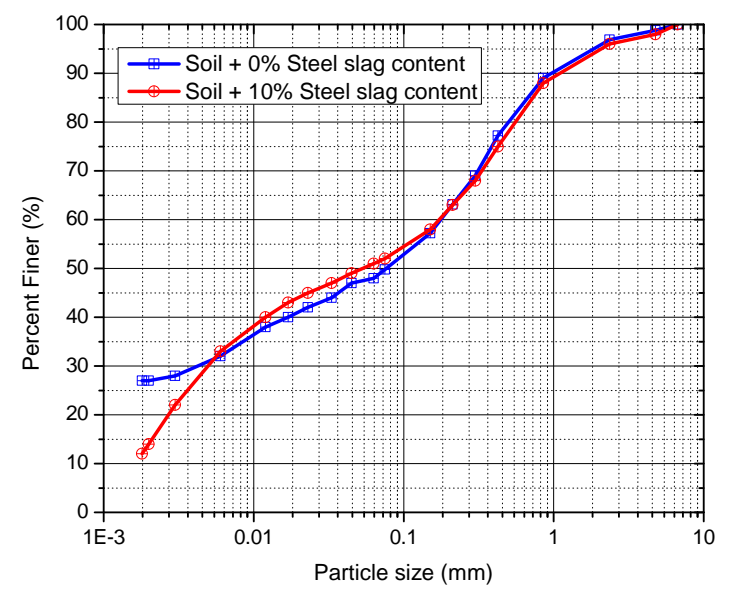

Fig. 4. Particle size distribution of natural soil and with $10 \%$ steel slag content

After a series of specific gravity tests, the average specific gravities of the soil and steel slag samples were determined to be 2.65 and 3.58 , respectively. Variation of specific gravity of the soil with changes in steel slag content is presented in Fig. 5 The increase in specific gravities of the soil-slag mixtures as the steel slag content increased was strongly correlated, $r=0.978$. The specific gravity of the soil was useful while determining the grain-size distribution in hydrometer analysis and computing the soil's void ratio.

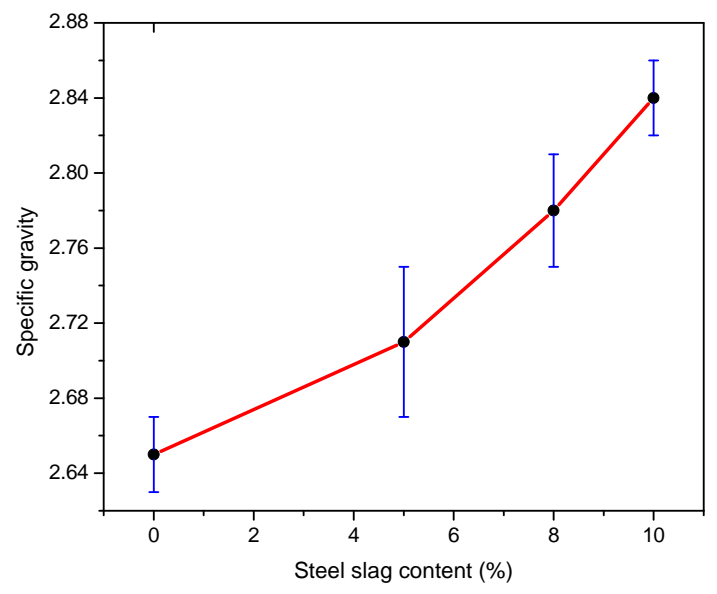

Fig. 5. Variation of specific gravity with slag content

Liquid and plastic limits, and the plasticity index of the lateritic soil sample were determined in order to characterize its condition by water content. With progressive increment in percentage of steel slag content in the lateritic soil, the liquid limit, plastic limit and plasticity index progressively decreased (Fig. 6). The decrease in plasticity indices of the soil-slag mixtures as the steel slag content increased was strongly correlated, $r=-0.997$.

The reduction in the clay-size particles of the soil-slag mixture and the consequent increase in its silt-size particles as 
Tab. 1. Geotechnical properties of unmodified soil

\begin{tabular}{|c|c|c|}
\hline & Properties & Quantity / Description \\
\hline \multirow[t]{6}{*}{ Gradation/Classification } & Gravel (>4.75 mm), \% & 1.2 \\
\hline & Sand $(0.075-4.75 \mathrm{~mm}), \%$ & 49.0 \\
\hline & Silt and Clay $(<0.075 \mathrm{~mm}), \%$ & 49.8 \\
\hline & AASHTO Soil Classification & \\
\hline & System & $A-7-6(b)$ \\
\hline & Unified Soil Classification System & CL - Sandy lean Clay \\
\hline \multirow[t]{10}{*}{ Physical } & Colour & Brown \\
\hline & Natural Moisture Content (\%) & 14.3 \\
\hline & Specific Gravity & 2.65 \\
\hline & Liquid Limit (\%) & 40.8 \\
\hline & Plastic Limit (\%) & 26.5 \\
\hline & Plasticity Index (\%) & 14.3 \\
\hline & Maximum Dry Unit weight $\left(\mathrm{kN} / \mathrm{m}^{3}\right)$ & 18.2 \\
\hline & Optimum Moisture Content (\%) & 17.5 \\
\hline & Permeability $(\mathrm{cm} / \mathrm{s})$ & $1.68 \times 10^{-4}$ \\
\hline & Swell Potential (\%) & 0.2 \\
\hline \multirow[t]{3}{*}{ Strength } & Unsoaked CBR (\%) & 51 \\
\hline & Soaked CBR (\%) & 49 \\
\hline & $\begin{array}{l}\text { Unconfined Compressive Strength } \\
\qquad\left(\mathrm{kN} / \mathrm{m}^{2}\right)\end{array}$ & 104 \\
\hline
\end{tabular}

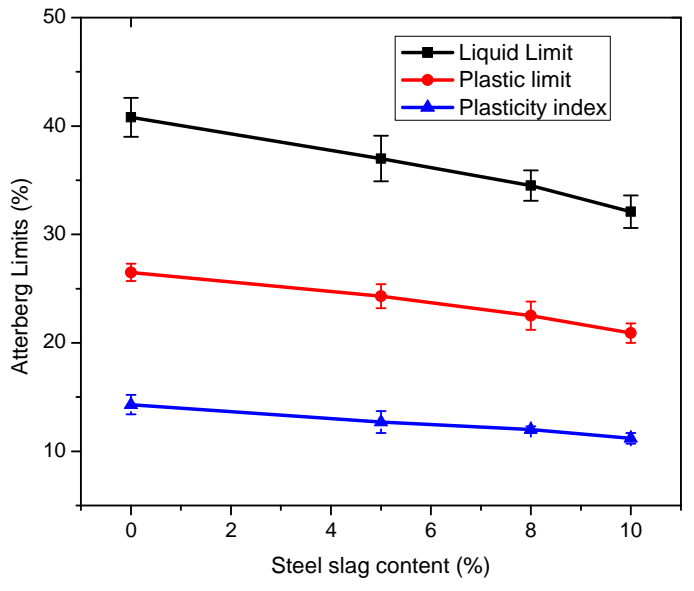

Fig. 6. Variation of Atterberg limits with slag content

shown in Fig. 4 are most likely responsible for the decrease in liquid and plastic limits, and plasticity index with progressive increase in slag content. This reduction in clay-size particles may be due to the replacement of lower valence cations present in the soil by $\mathrm{Ca}^{2+}$ and $\mathrm{Mg}^{2+}$ present in the steel slag, reducing the size of the diffused water layer, thereby allowing the clay-sized particles in the soil and slag to approach each other more closely and get clumped-together to form silt-size particles. This behavior is similar to that of lime modification of soils that leads to greater workability of the soil except that for lime-treated soils, their plastic limits were found to be higher than those of the natural soils. Fig. 7 shows that the natural soil, which was classified as A-7-6 on the plasticity chart, was improved to an A-6 soil by the addition of steel slag.
Variation of each of the maximum dry unit weight and optimum moisture content (OMC) with slag content is shown in Fig. 8 The maximum dry unit weight of the soil slightly increased with higher steel slag contents. The increase in maximum dry unit weights of the soil-slag mixtures as the steel slag content increased was strongly correlated, $r=0.939$.

The increase in maximum dry unit weight with increasing steel slag content was expected considering the higher specific gravity of the steel slag compared with that of the soil.

The optimum moisture content of the soil decreased as the amount of steel slag in the mixture increased from 0 to $8 \%$ before a slight increase for the $10 \%$ slag content. The decrease in optimum moisture content of the soil-slag mixtures as the steel slag content increased was strongly correlated, $r=-0.965$.

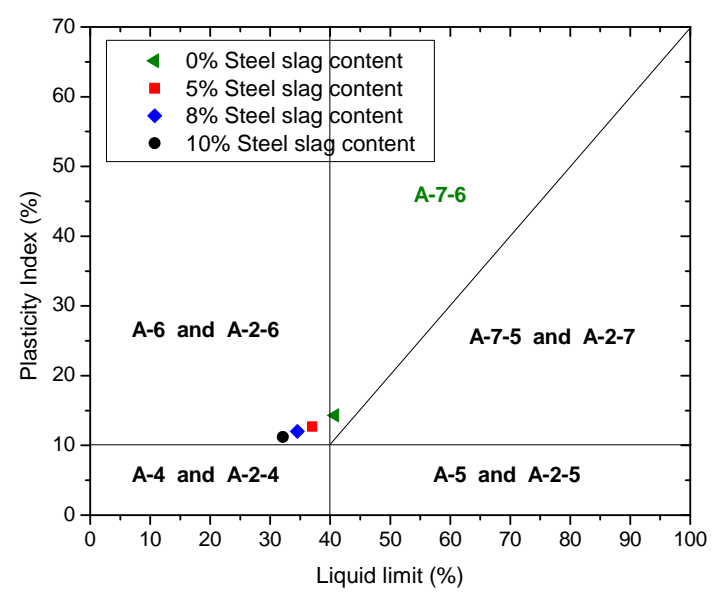

Fig. 7. AASHTO plasticity chart showing the plots of the mean values of the natural and modified soil samples 


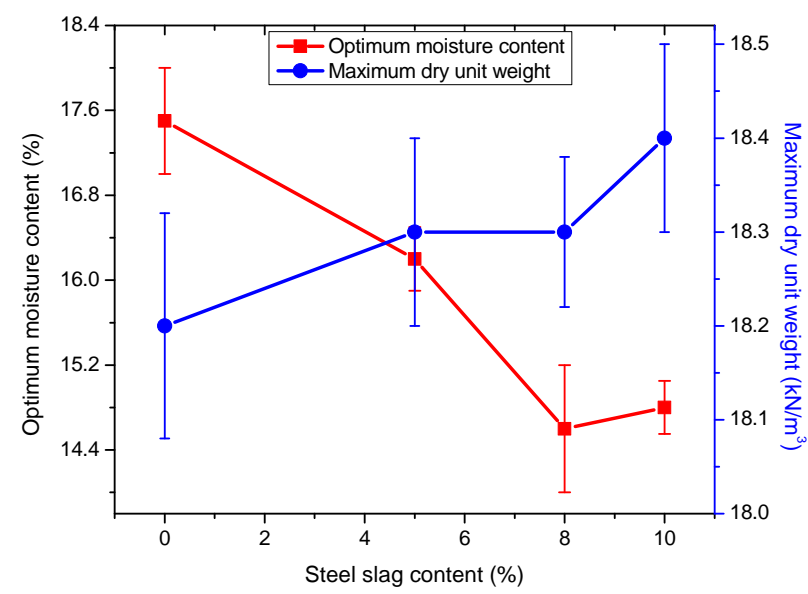

Fig. 8. Variation of compaction characteristics with slag content

The decrease in optimum moisture content with higher steel slag content from 0 to $8 \%$ before a slight increase can be attributed to a reduction in the size of the diffused water layer that resulted in the agglomeration (clumping-together) of the claysize particles; making the soil require less water to reach optimum.

The variation in unsoaked and soaked CBR with slag content is shown in Fig. 9. The unsoaked CBR value for the soil progressively increased from $51 \%$ for the $0 \%$ slag content to $91 \%$ for $8 \%$ slag content before a decrease to $79 \%$ for $10 \%$ steel slag content was experienced. The increase in unsoaked CBR values of the soil-slag mixtures as the steel slag content increased was strongly correlated, $r=0.856$.

The soaked CBR value initially decreased from from $49 \%$ for the $0 \%$ slag content to $25 \%$ for $5 \%$ slag content before a progressive increase to $30 \%$ for $10 \%$ steel slag content. The decrease in soaked CBR values of the soil-slag mixtures as the steel slag content increased was strongly correlated, $r=-0.770$.

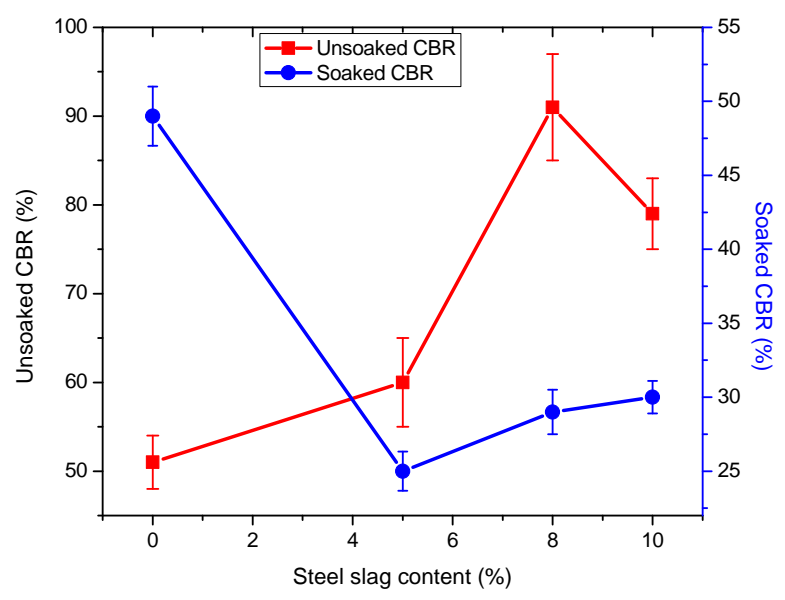

Fig. 9. Variation of CBR with slag content

The swell potential of the soil progressively reduced with higher slag content, as seen in Fig. 10. The decrease in swell potential of the soil-slag mixtures as the steel slag content increased was perfectly correlated, $r=-1.00$.

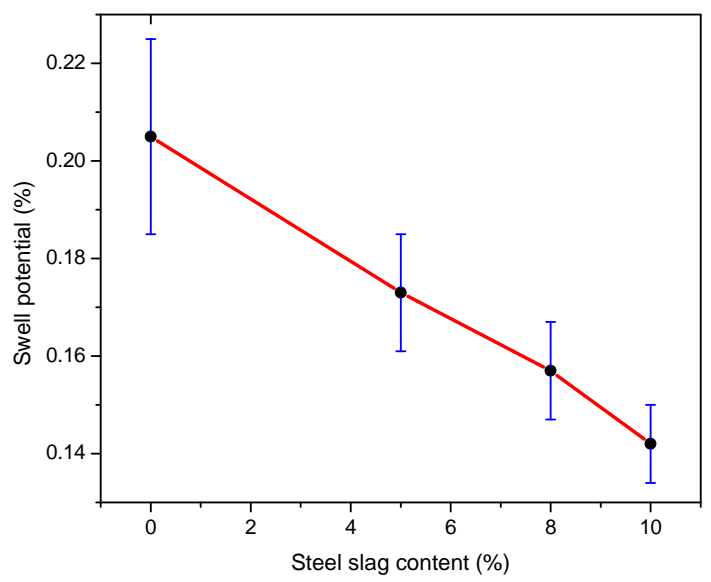

Fig. 10. Variation of swell potential with slag content

The reduction in the swell potential is most likely due to the reduction in plasticity of the soil as the steel slag content increased. The swell potential was generally low strengthening the claim of the predominance of kaolinite, which is not expansive.

The unconfined compressive strength (UCS) of the soil, as shown in Fig. 11, increased with increasing slag content from $104.0 \mathrm{kN} / \mathrm{m}^{2}$ for $0 \%$ slag content to $170.7 \mathrm{kN} / \mathrm{m}^{2}$ for $8 \%$ slag content, before decreasing. The increase in UCS of the soil-slag mixture as the steel slag content increased was strongly correlated, $r=0.718$.

The results of unsoaked CBR and UCS suggest that $8 \%$ of steel slag in the soil could be the limit for the improvement of the uncured strength of the soil. This improvement is most likely a consequence of the increase in internal friction and shear strength of the silt-size particles that resulted from the agglomeration of the clay-size particles.

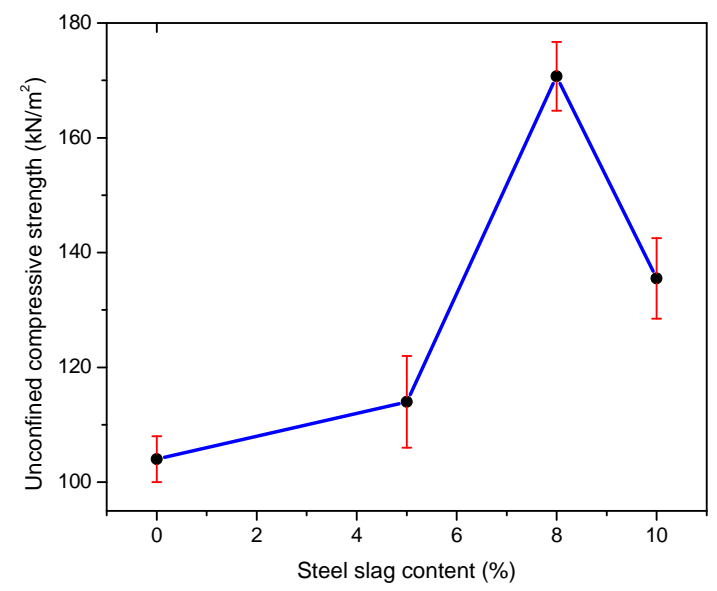

Fig. 11. Variation of UCS with slag content 
The variation in permeability of the soil with slag content is shown in Fig. 12. The permeability increased with increasing slag content from $1.68 \times 10^{-4} \mathrm{~cm} / \mathrm{s}$ (for $0 \%$ slag content) to $2.55 \times 10^{-4} \mathrm{~cm} / \mathrm{s}$ (for $10 \%$ slag content). The increase in permeability of the soil-slag mixtures as the steel slag content increased was strongly correlated, $r=0.918$.

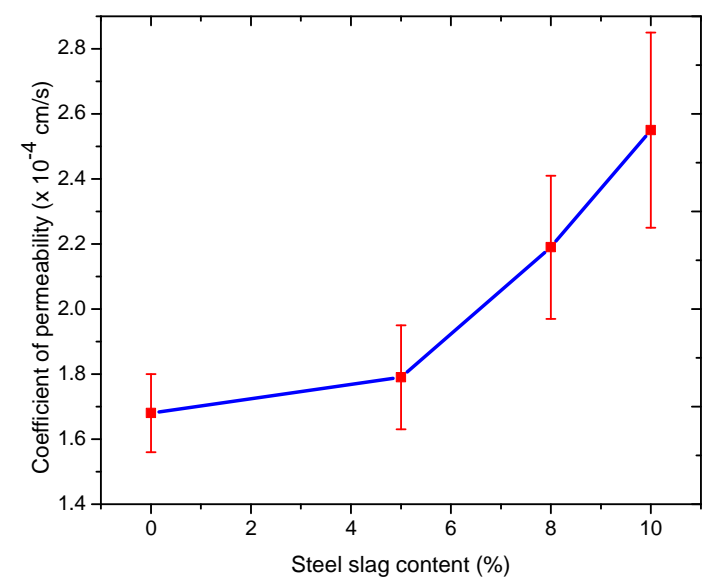

Fig. 12. Variation of permeability with slag content

The formation of silt-size particles due to the agglomeration of clay-size particles of the soil and steel slag, with increasing steel slag content and the consequent increase in the void ratio of the soil-slag mixtures, reduced the moisture-holding capacity of the soil. This, consequently, accounts for the increase in the coefficient of permeability with increasing steel slag content.

\section{Discussion}

Recent research works [3, 8] have encouraged the use of recycled products for road construction applications. Few research works [11, 16] have been conducted to use pulverized or steel slag fines as a potential soil modifier or stabilizer. While this few works used basic oxygen steel slag, no study has been found in the open literature that assessed the potential use of EAF steel slag for soil improvement or the potential use of steel slag for improving the geotechnical properties of a lateritic soil. Malasavage et al. [11] studied the use of steel slag fines to improve a dredged material (A - 7 - 6) for use as a synthetic fill material. Poh et al. [16] studied the use of steel slag fines for stabilizing English China and Mercia mudstone. Of the two research works, that of Malasavage et al. [11] seems more related to this study.

The effects of the addition of pulverized steel slag on the specific gravity, particle size distribution, consistency limits and compaction characteristics are similar to the effects reported by Malasavage et al. [11]. Poh et al. [16] did not report the effects of the addition of steel slag fines on the index properties of the English China clay and Mercia mudstone used.

As the steel slag content increased in this study, the UCS of the lateritic soil increased. This result is similar to the reported effect of the addition of basic oxygen steel slag fines on English China clay and Mercia mudstone [16]. Malasavage et al. [11] reported a decrease in permeability of the dredged material with increasing steel slag fines content.

\section{Conclusion}

This study provides experimental insights that show that pulverized steel slag was beneficially used to improve the plasticity, uncured strength and drainage characteristics of the lateritic soil without any adverse swell behaviour observed.

The improvement in the uncured strength of the soil was limited to the application of $8 \%$ steel slag to the soil. Addition of $8 \%$ of steel slag to the soil increased its unsoaked CBR by $40 \%$ and its unconfined compressive strength by $66.7 \mathrm{kN} / \mathrm{m}^{2}$, while the liquid limit, plastic limit and plasticity index were reduced by $6.3 \%, 4.0 \%$ and $2.3 \%$, respectively. Cation exchange between the soil and the steel slag was identified as the major factor that influenced the modification of the engineering properties of the soil by the addition of steel slag. It influenced the reduction in the diffused water layer and led to the agglomeration of clay-size particles in the soil-slag mixtures.

Steel slag (instead of being disposed-off) is recommended for use as a low-cost modifier or stabilizer, of local soils with similar engineering properties as that used in this study, for subgrade improvement or constructing a subgrade capping layer during road construction

\section{Acknowledgement}

I hereby acknowledge the supervision of part of this research work by Prof. J. B. Adeyeri.

\section{References}

1 Ahmedzade P, Sengoz B, Evaluation of steel slag coarse aggregate in hot mix asphalt concrete, Journal of Hazardous Materials, 165(1-3), (2009), 300-305, DOI 10.1016/j.jhazmat.2008.09.105

2 Akinwumi II, Adeyeri JB, Ejohwomu OA, Effects of Steel Slag Addition on the Plasticity, Strength, and Permeability of Lateritic Soil, International Conference of Sustainable Design, Engineering and Construction 2012, In: Chong WKO, Gong J, Chang J, Siddiqui MK (eds.), ICSDEC 2012, ICSDEC Conference Proceedings, American Society of Civil Engineers; Texas, United States, 2013, pp. 457-464, DOI 10.1061/9780784412688.055

3 Akinwumi II, Diwa D, Obianigwe N, Effects of crude oil contamination on the index properties, strength and permeability of lateritic clay, International Journal of Applied Sciences and Engineering Research, 3(4), (2014), 816824, DOI $10.6088 /$ ijaser.030400007

4 Altun A, Yilmaz I, Study on steel furnace slags with high $\mathrm{MgO}$ as additive in Portland cement, Cement and Concrete Research, 32(8), (2002), 1247-1249, DOI 10.1016/S0008-8846(02)00763-9

5 Borovsky T, Kijac J, Bulko B, Domevec M, Havran J, The influence of slag composition on the distribution of manganese between slag and metal in the electric arc furnace, Acta Metallurgica Slovaca, 18(1), (2012), 28-33.

6 Methods of Testing Soils for Civil Engineering Purposes, BS 1377, British Standards Institution; London, England, 1990.

7 Budhu M, Soil mechanics and foundations, third edition, John Wiley \& Sons, Inc.; New Jersey, 2011. 
8 Fi I, Szentpeteri I, A Mechanistic-Empirical Approach for Asphalt Overlay Design of Asphalt Pavement Structures, Periodica Polytechnica Civil Engineering, 58(1), (2014), 55-62, DOI 10.3311/PPci.7408

9 Juckes LM, The volume stability of modern steelmaking slags, Mineral Processing and Extractive Metallurgy, 112(3), (2003), 177-197, DOI $10.1179 / 037195503225003708$

10 Maignien R, Survey of research on laterites, United Nations Educational, Scientific and Cultural Organization; Paris, 1964.

11 Malasavage NE, Jagupilla S, Grubb DG, Wazne M, Coon WP, Geotechnical Performance of Dredged Material-Steel Slag Fines Blends: Laboratory and Field Evaluation, Journal of Geotechnical and Geoenvironmental Engineering, 138(8), (2012), 981-991, DOI 10.1061/(ASCE)GT.19435606.0000658

12 Manso JM, Polanco JA, Losanez M, Gonzalez JJ, Durability of concrete made with EAF slag as aggregate, Cement and Concrete Composites, 28(6), (2006), 528-534, DOI 10.1016/j.cemconcomp.2006.02.008

13 Monshi A, Asgarani MK, Producing Portland cement from iron and steel slags and limestone, Cement and Concrete Research, 29(9), (1999), 13731377, DOI 10.1016/S0008-8846(99)00028-9

14 Motz H, Geiseler J, Products of steel slags an opportunity to save natural resources, Waste Management, 21(3), (2001), 285-293, DOI 10.1016/S0956053X(00)00102-1

15 Nigerian General Specifications, Roads and Bridges, Federal Ministry of Works; Lagos, Nigeria, 1997.

16 Poh HY, Ghataora GS, Ghazireh N, Soil Stabilization Using Basic Oxygen Steel Slag Fines, Journal of Materials in Civil Engineering, 18(2), (2006), 229-240, DOI 10.1061/(ASCE)0899-1561(2006)18:2(229)

17 Schellmann W, Considerations on the definition and classification of laterites, International Seminar on Lateritisation Processes 1979, In: Krishnaswamy VS, Geological Survey of India (eds.), Lateritisation Processes, Oxford \& IBH Publishing Co.; Trivandrum, India, 1981, pp. 1-10.

18 Shi C, Steel Slag-Its Production, Processing, Characteristics, and Cementitious Properties, Journal of Materials in Civil Engineering, 16(3), (2004), 230-236, DOI 10.1061/(ASCE)0899-1561(2004)16:3(230)

19 Shi C, Day RL, Early strength development and hydration of alkali-activated blast furnace slag/fly ash blends, Advances in Cement Research, 11(4), (1999), 189-196, DOI 10.1680/adcr.1999.11.4.189

20 Structural design of flexible pavements for interurban and rural roads, TRH4, Committee of land transport officials, Ministry of Transport; Pretoria, South Africa, 1996.

21 Overseas Road Note 31: A guide to the structural design of bitumen-surfaced roads in tropical and sub-tropical countries, Transport Research Laboratory; Berkshire, England, 1993.

22 Tsakiridis PE, Papadimitriou GD, Tsivilis S, Koroneos S, Utilization of steel slag for Portland cement clinker production, Journal of Hazardous Materials, 152(2), (2008), 805-811, DOI 10.1016/j.jhazmat.2007.07.093

23 Wang G, Wang Y, Gao Z, Use of steel slag as a granular material: Volume expansion prediction and usability criteria, Journal of Hazardous Materials, 184(1-3), (2010), 555-560, DOI 10.1016/j.jhazmat.2010.08.071

24 Yildirim IZ, Prezzi M, Chemical, Mineralogical, and Morphological Properties of Steel Slag, Advances in Civil Engineering, 2011(2011), (2011), 1-13, DOI $10.1155 / 2011 / 463638$ 